\title{
Interleukin-1 $\beta$ Immunoreactivity and Microglia Are Enhanced in the Rat Hippocampus by Focal Kainate Application: Functional Evidence for Enhancement of Electrographic Seizures
}

\author{
Annamaria Vezzani, ${ }^{1}$ Mirko Conti, ${ }^{1}$ Ada De Luigi, ${ }^{2}$ Teresa Ravizza, ${ }^{1}$ Daniela Moneta, ${ }^{1}$ Francesco Marchesi, ${ }^{1}$ \\ and Maria Grazia De Simoni ${ }^{2}$ \\ ${ }^{1}$ Laboratory of Experimental Neurology and ${ }^{2}$ Laboratory of Inflammation and Nervous System Diseases, Department of \\ Neuroscience, Istituto di Ricerche Farmacologiche "Mario Negri," 20157 Milan, Italy
}

Using immunocytochemistry and ELISA, we investigated the production of interleukin (IL)- $1 \beta$ in the rat hippocampus after focal application of kainic acid inducing electroencephalographic (EEG) seizures and CA3 neuronal cell loss. Next, we studied whether EEG seizures per se induced IL-1 $\beta$ and microglia changes in the hippocampus using bicuculline as a nonexcitotoxic convulsant agent. Finally, to address the functional role of this cytokine, we measured the effect of human recombinant (hr)IL-1 $\beta$ on seizure activity as one marker of the response to kainate.

Three and $24 \mathrm{hr}$ after unilateral intrahippocampal application of $0.19 \mathrm{nmol}$ of kainate, IL-1 $\beta$ immunoreactivity was enhanced in glia in the injected and the contralateral hippocampi. At $24 \mathrm{hr}$, $\mathrm{IL}-1 \beta$ concentration increased by 16 -fold $(p<0.01)$ in the injected hippocampus. Reactive microglia was enhanced with a pattern similar to IL-1 $\beta$ immunoreactivity. Intrahippocampal ap- plication of $0.77 \mathrm{nmol}$ of bicuculline methiodide, which induces EEG seizures but not cell loss, enhanced IL-1 $\beta$ immunoreactivity and microglia, although to a less extent and for a shorter time compared with kainate. One nanogram of $(\mathrm{hr}) \mathrm{IL}-1 \beta$ intrahippocampally injected 10 min before kainate enhanced by $226 \%$ the time spent in seizures $(p<0.01)$. This effect was blocked by coinjection of $1 \mu \mathrm{g}(\mathrm{hr}) \mathrm{IL}-1 \beta$ receptor antagonist or $0.1 \mathrm{ng}$ of 3-((+)-2-carboxypiperazin-4-yl)-propyl-1-phosphonate, selective antagonists of IL-1 $\beta$ and NMDA receptors, respectively.

Thus, convulsant and/or excitotoxic stimuli increase the production of IL-1 $\beta$ in microglia-like cells in the hippocampus. In addition, exogenous application of $\mathrm{IL}-1 \beta$ prolongs kainateinduced hippocampal EEG seizures by enhancing glutamatergic neurotransmission.

Key words: bicuculline; cytokines; EEG; epilepsy; interleukin (IL)-1Ra; inflammation; neurodegeneration
The proinflammatory cytokines constitute a group of polypeptide hormones, which were first identified as soluble mediators within the immune system (Schobitz et al., 1994). Recently, cytokines and their receptors have been located in many other tissues, including the peripheral and central nervous systems (Hopkins and Rothwell, 1995). Receptors for interleukin (IL)- $1 \beta$ have been found in rodent brain at particularly high density in the hippocampus, where they are presumably located on dendrites of granule cells (Takao et al., 1990; Ban et al., 1991; Nishiyori et al., 1997). Both neurons and glia have been shown to produce IL- $1 \beta$, thus indicating a local source of synthesis in CNS (Benveniste, 1992; Bartfai and Schultzberg, 1993; Hopkins and Rothwell, 1995).

The presence of cytokines in CNS has raised many questions about their function and mechanisms of action. Besides their well known central actions including effects on the hypothalamopituitary-adrenal axis, fever responses, somnogenic effects, and modification of the peripheral immune response (Schobitz et al., 1994; Hopkins and Rothwell, 1995), some cytokines have been

\footnotetext{
Received July 31, 1998; revised Feb. 25, 1999; accepted March 22, 1999.

This work was supported by Telethon Grant E.573. Rat IL-1 $\beta$ ELISA reagents and rat IL $-1 \beta$ antibody were kindly provided by Dr. S. Poole. (hr)IL-1 $\beta$ and (hr)IL-1Ra were kindly provided by Dr. Diana Boraschi. We are grateful to Dr. R. Samanin for kindly revising this manuscript and to Andrea Borroni and Carlo Perego for their contribution to part of this study.

Correspondence should be addressed to Dr. Annamaria Vezzani, Laboratory of Experimental Neurology, Istituto di Ricerche Farmacologiche "Mario Negri," Via Eritrea 62, 20157 Milan, Italy.

Copyright (C) 1999 Society for Neuroscience $\quad 0270-6474 / 99 / 195054-12 \$ 05.00 / 0$
}

recently shown to affect many neurotransmitters, including noradrenaline, serotonin, GABA, and acetylcholine (Rothwell and Hopkins, 1995; De Simoni and Imeri, 1998), and the expression of various neuropeptides and neurotrophic factors in several brain regions (Scarborough et al., 1989; Spranger et al., 1990; Lapchak et al., 1993). In particular, electrophysiological findings have shown that relatively low concentrations of IL- $1 \beta$, IL-6, and tumor necrosis factor- $\alpha$ (TNF- $\alpha$ ) inhibit long-term potentiation (Katsuki et al., 1990; Bellinger et al., 1993; Cunningham et al., 1996), affect excitatory synaptic transmission (Coogan and O’Connor, 1997; D’Arcangelo et al., 1997; Zeise et al., 1997), and modify ionic conductances, particularly $\mathrm{Cl}^{-}$and $\mathrm{Ca}^{2+}$ currents (Miller et al., 1991; Plata-Salamàn and ffrench-Mullen, 1992).

The involvement of cytokines in neuronal network excitability was recently suggested by the evidence that convulsant drugs increase mRNA levels of IL- $1 \beta$, IL- 6 , and TNF- $\alpha$ as well as of type 2-IL-1 receptor and IL-1 receptor antagonist $(\mathrm{Ra})$ in rat forebrain within hours of seizure induction (Minami et al., 1990, 1991; Nishiyori et al., 1997; Eriksson et al., 1998). In particular, in situ hybridization analysis of IL- $1 \beta$ and IL-1Ra mRNAs after systemic injection of kainic acid in rats has shown that these transcripts were significantly induced in microglial cells in the hippocampus as well as in other areas of the limbic system (Yabuuchi et al., 1993; Eriksson et al., 1998). Interestingly, autoradiographic analysis of the binding of radiolabeled IL-1 to rodent brain has revealed a high density of type I receptors in neurons of the dentate gyrus (Takao et al., 1990; Ban et al., 1991), thus suggesting that IL- $1 \beta$ is synthesized in glia and then secreted 


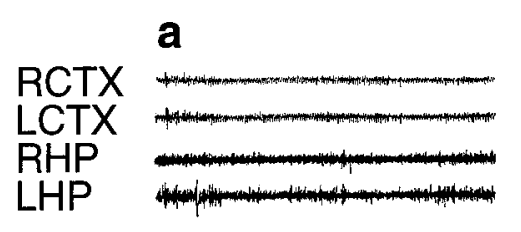

RCTX

e

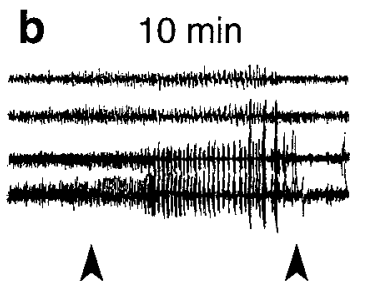

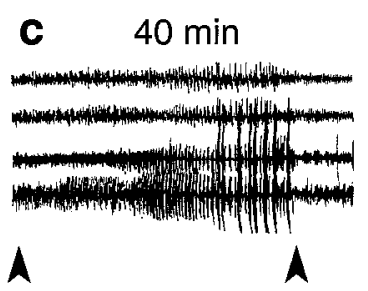

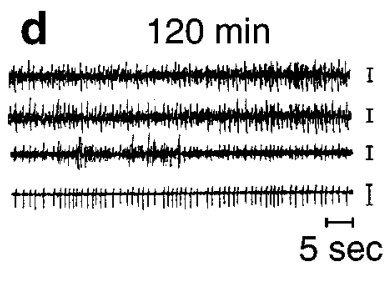

\section{LCTX \\ $\mathrm{RHP}$ \\ LHP}

$5 \mathrm{~min}$

How

g

$60 \mathrm{~min}$

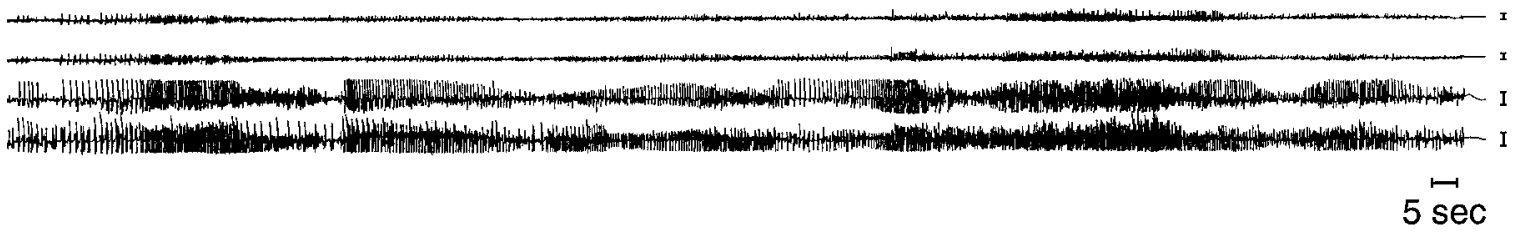

Figure 1. Sections of the EEG tracing from a rat injected unilaterally in the dorsal hippocampus with $0.19 \mathrm{nmol}$ of kainic acid $(a-d)$ or $0.77 \mathrm{nmol}$ of bicuculline methiodide $(e-g) . a, e$, Baseline recordings; $b, c$, typical seizures; $d$, spiking activity; $f, g$, seizure activity in continuity with synchronous spiking. RCTX, LCTX, Right and left cortex, respectively; RHP, LHP, right and left hippocampus, respectively. Calibration, $100 \mu \mathrm{V}$. Arrowheads in $c$ and $d$ delimit the duration of discrete seizure episodes. Time elapsed from the injection of convulsant drugs is indicated.

in the extracellular space for interacting with its specific receptors. In this regard, a larger release of inflammatory cytokines has been described in hippocampal slices of epileptic rats (de Bock et al., 1996).

Evidence in humans also indicates that IL-1 is produced in higher amounts in epilepsy, because IL- $1 \alpha$-immunoreactive microglia is enhanced in surgically resected temporal lobe tissue (Sheng et al., 1994).

Although the synthesis of cytokines appears to be tightly regulated at the transcriptional level (Schobitz et al., 1994), the data available so far in experimental models of seizures merely analyzed IL-1 mRNA expression, thus not providing direct evidence that this cytokine is indeed produced in higher amount in brain tissue.

In this study, we investigated (1) whether IL-1 $\beta$ production is enhanced in the hippocampus after focal application of kainate inducing both electroencephalographic (EEG) seizures and neuronal cell loss; (2) whether IL-1 $\beta$ production was enhanced in the hippocampus by seizures per se using bicuculline methiodide as a nonexcitotoxic convulsant agent; (3) the cell types involved in this effect compared with the pattern of activated microglial cells, because they have been described as a major source of IL-1 $\beta$ in CNS (Giulian et al., 1986); and (4) the effect of intrahippocampal application of (hr)IL-1 $\beta$ on kainate-induced seizures; (5) finally, we probed the hypothesis that glutamate was involved in the effect of (hr)IL-1 $\beta$ on kainate-induced seizures.

\section{MATERIALS AND METHODS}

Experimental animals. Male Sprague Dawley rats (250-280 gm) were purchased from Charles River (Calco, Italy), and they were housed at a constant temperature $\left(23^{\circ} \mathrm{C}\right)$ and relative humidity $(60 \%)$ with free access to food and water and a fixed $12 \mathrm{hr}$ light/dark cycle.

Procedures involving animals and their care were conducted in conformity with the institutional guidelines that are in compliance with national (4DL N116, GU, suppl 40, 18-2-1992) and international laws and policies (Europen Community Council Directive 86/609, OJ L 358, 1, December 12, 1987; National Institutes of Health Guide for the Care and Use of Laboratory Animals, US National Reasearch Council, 1996).

Placement of cannula and electrodes for EEG recordings. Rats were surgically implanted with cannula and electrodes under stereotaxic guidance as described in detail (Vezzani et al., 1986). Briefly, rats were deeply anesthetized using Equithesin (1\% phenobarbital and 4\% chloral hydrate; $3 \mathrm{ml} / \mathrm{kg}$, i.p). Two screw electrodes were placed bilaterally over the parietal cortex, along with a ground lead positioned over the nasal sinus. Bipolar nichrome wire insulated electrodes $(60 \mu \mathrm{m})$ were implanted bilaterally into the dentate gyrus of the dorsal hippocampus (septal pole), and a cannula (22 gauge) was unilaterally positioned on top of the dura and glued to one of the depth electrodes for the intrahippocampal infusion of drugs. The coordinates from bregma for implantation of the electrodes were (in $\mathrm{mm}$ ): anteroposterior -3.5 ; lateral, 2.4; and 3 below dura with the nose bar set at -2.5 (Paxinos and Watson, 1986). The electrodes were connected to a multipin socket (March Electronics, Bohemia, NY) and, together with the injection cannula, were secured to the skull by acrylic dental cement. The experiments were performed $7 \mathrm{~d}$ after surgery when the animals did not show any sign of pain or discomfort.

EEG recordings and intrahippocampal injection of drugs. The procedures for recording the EEG and intracerebral injection of drugs have been previously described (Vezzani et al., 1986). Briefly, the animals were allowed to acclimatize in a Plexiglas cage $(25 \times 25 \times 60 \mathrm{~cm})$ for a minimum of $10 \mathrm{~min}$ before the recording to enable them to adapt to the new environment. The rats were then connected to the lead socket, and a 15-30 min baseline recording was made to establish an adequate control period. EEG recordings (four-channel EEG polygraph, BP8; Battaglia Rangoni, Bologna, Italy) were made continuously during drug 


\section{IL-1 $\beta$}
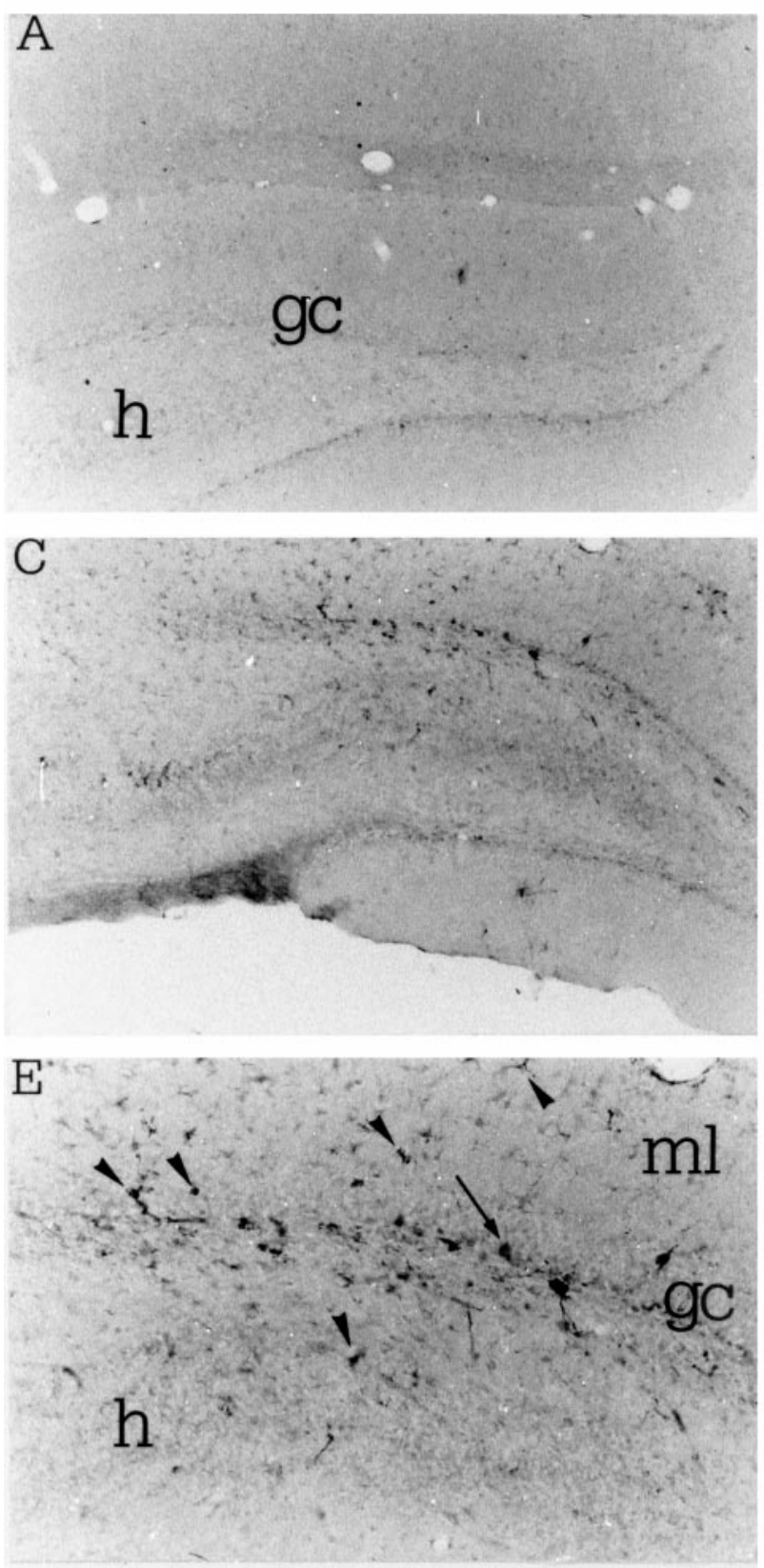

MICROGLIA
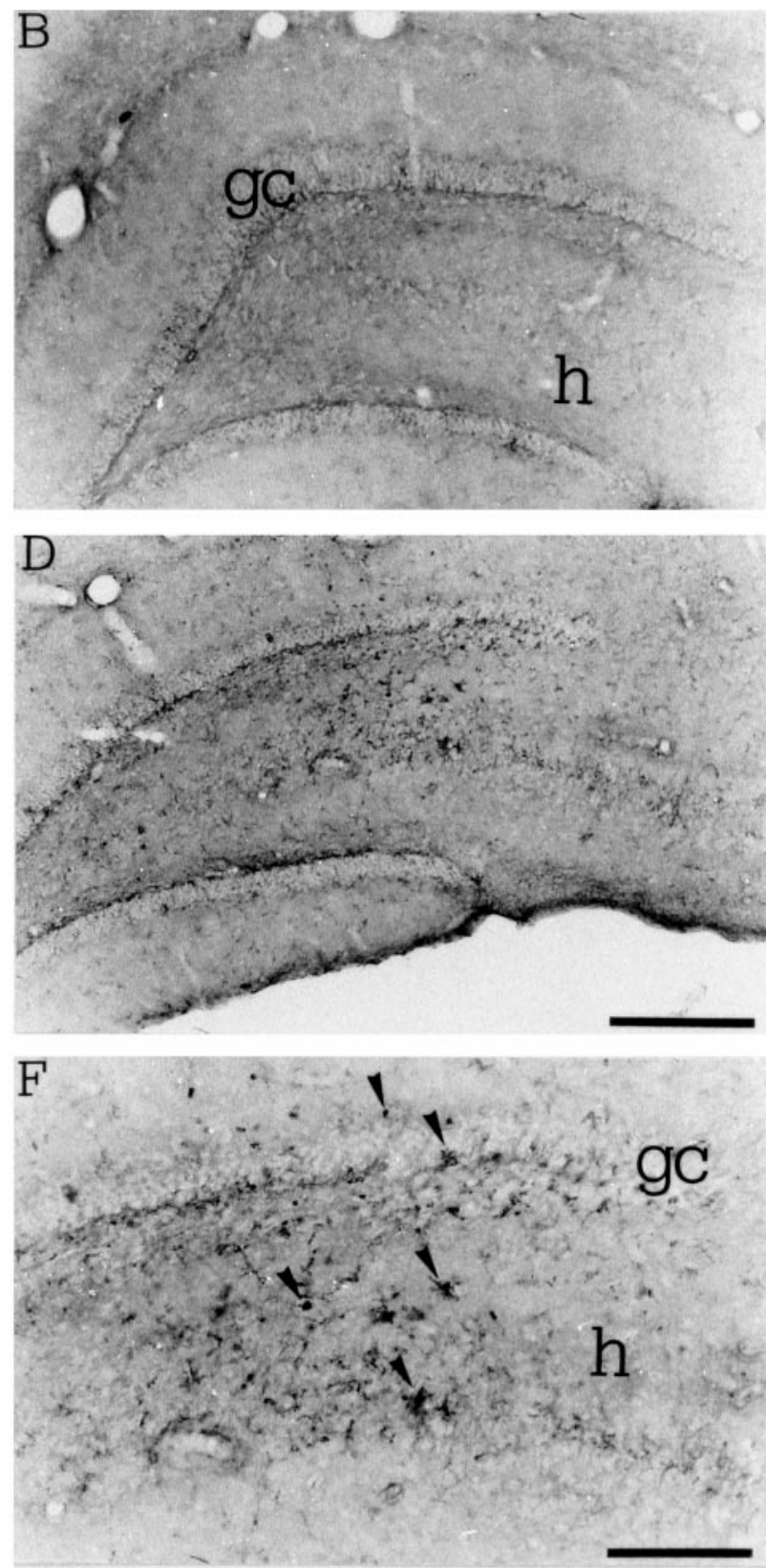

Figure 2. Photomicrographs showing IL-1 $\beta$ immunoreactivity $(A, C, E)$ and B4-isolectin-positive microglia $(B, D, F)$ in coronal sections of the rat dorsal hippocampus $3 \mathrm{hr}$ after a local injection of PBS saline $(A, B)$ or 0.19 nmol of kainic acid $(C-F)$. $E, F$, Higher magnifications of pictures respectively depicted in $C$ and $D$. IL-1 $\beta$ immunoreactivity was markedly increased in glia-like cells located in the granule cell layer and in the molecular layer ( $m l$ ) of the dentate gyrus (arrowheads). These cells have a darkly stained cell body and branched processes, and some of them have an ameboid shape resembling microglia phenotype $(E)$. Scattered cells with neuronal appearance were also observed $(E$, arrow). B4-isolectin-positive microglia was also increased in the same regions $(D, F)$. Note that microglia cells and their processes were interposed between granule cells $(g c)$ and CA3 pyramidal neurons in the hilus $(h)$. Scale bars: $A-D, 500 \mu \mathrm{m} ; E, F, 200 \mu \mathrm{m}$.

injection and up to $180 \mathrm{~min}$ after drug infusion. All the injections were made to unanesthetized rats using a needle (28 gauge) protruding $3 \mathrm{~mm}$ below the cannula.

Analysis of the EEG. Seizures were induced in rats by intrahippocampal application of nanomole amounts of kainic acid, a glutamate analog acting on kainate-type glutamate receptors (Watkins, 1978), or bicuculline methiodide, a GABA-A receptor antagonist (Curtis et al., 1970), and they were measured by EEG analysis. Kainate-induced seizures have been previously shown to provide a sensitive measure of the anticonvulsant activity of drugs, and they are reportedly associated with neuronal cell loss restricted to the CA3 pyramidal cells in the injected hippocampus (Vezzani et al., 1991; Gariboldi et al., 1998). EEG seizures induced by relatively low doses of bicuculline $(<1 \mathrm{nmol})$ are not associated with nerve cell loss, thus representing a nonlesional model of seizure activity (Turski et al., 1985).

The EEG recording of each rat was analyzed visually to detect any activity different from baseline. Seizures were defined by the occurrence of discrete episodes consisting of the simultaneous occurrence of at least two of the following alterations in all four leads of recordings: highfrequency and/or multispike complexes and/or high-voltage synchro- 
IL-1 $\beta$
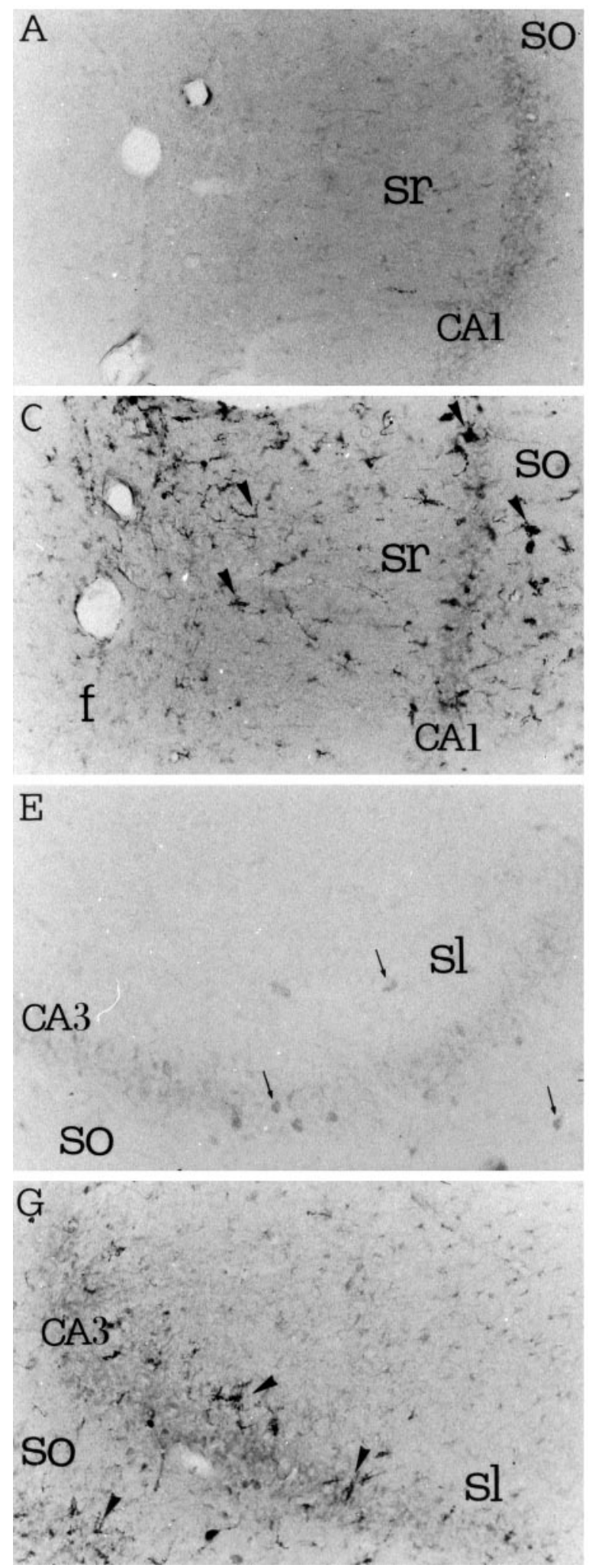

MICROGLIA
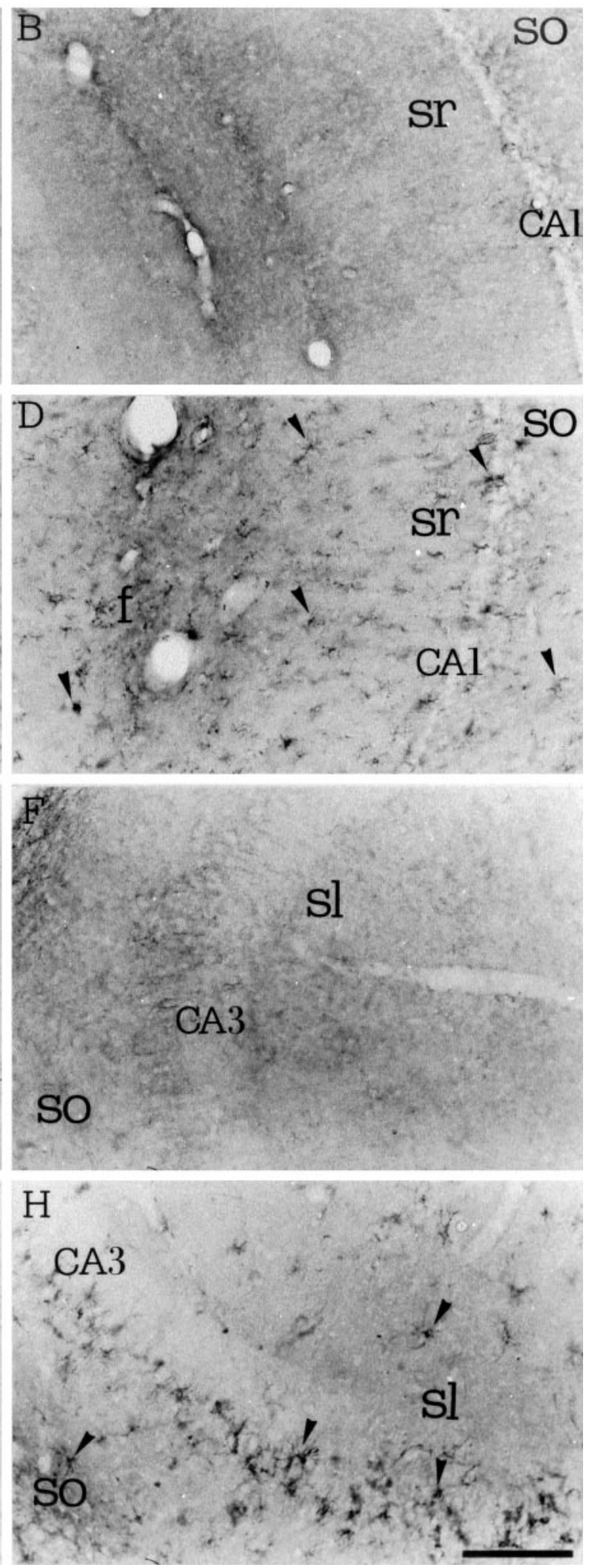

Figure 3. High-magnification photomicrographs showing IL-1 $\beta$ immunoreactivity $(A, C, E, G)$ and B4-isolectin-positive microglia $(B, D, F, H)$ in coronal sections of the CA1 $(A-D)$ and CA3 $(E-H)$ areas of the rat dorsal hippocampus $3 \mathrm{hr}$ after a local injection of PBS $(A, B, E, F)$ or $0.19 \mathrm{nmol}$ of kainic acid $(C, D, G, H)$. IL-1 $\beta$-positive neurons were lightly stained in CA3 pyramidal layer and stratum oriens (so) and lucidum (sl) in control sections (E, arrows). IL-1 $\beta$ immunoreactivity and B4-isolectin positive-microglia (round-shaped cells as well as cells with ramified processes) were enhanced in pyramidal layer $(C A 1, C A 3)$, stratum oriens and radiatum $(s r)$ of CA1 and CA3 areas, and stratum lucidum CA3 ( $C, D, G, H$, arrowheads). $f$, Fissura hippocampi. Scale bar, $200 \mu \mathrm{m}$. 
IL-1 $\beta$
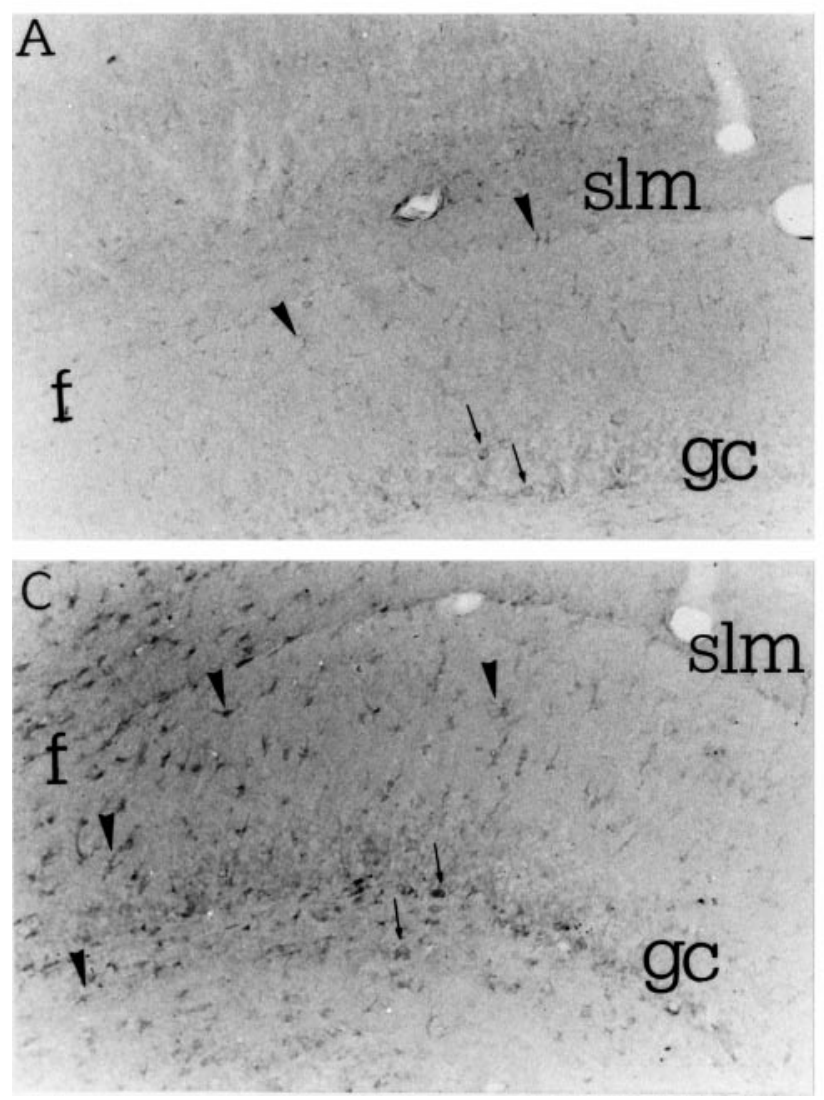

MICROGLIA
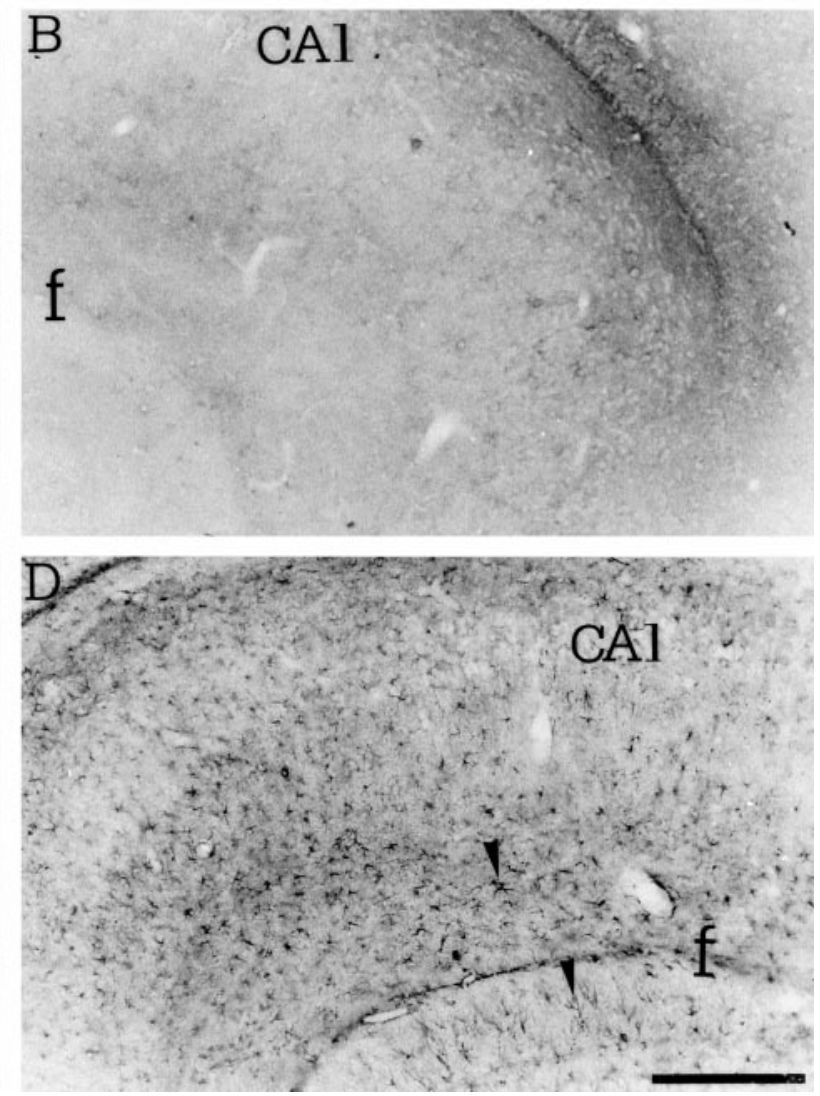

Figure 4. High-magnification photomicrographs showing IL-1 $\beta$ immunoreactivity $(A, C)$ and B4-isolectin-positive microglia $(B, D)$ in coronal sections of the rat dorsal hippocampus $24 \mathrm{hr}$ after a local injection of PBS $(A, B)$ or $0.19 \mathrm{nmol}$ of kainic acid $(C, D)$. Note the diff use pattern of enhanced IL-1 $\beta$ immunoreactivity in glia-like cells $(C)$ and the widespread staining of B4-isolectin-positive microglia $(D)$. Scattered IL-1 $\beta$ immunoreactive neurons were also observed $(A, C$, arrows). $g c$, Granule cells; $f$, fissura hippocampi; $C A 1$, CA1 pyramidal layer; slm, Stratum lacunosum moleculare. Scale bar, $200 \mu \mathrm{m}$.

nized spike or wave activity. These episodes were typically observed in the first 120 min after kainate injection (Fig. 1b,c). Synchronous spiking was often observed when seizures subsided (Fig. $1 d$ ). Seizure episodes after bicuculline were not discrete but in continuity with synchronous spiking (Fig. 1f,g). Epileptic-like activity was restricted to the first $90 \mathrm{~min}$ after bicuculline injection.

The quantitative parameters chosen to quantify seizure activity after kainate were the latency to the first seizure (onset), the total number of seizures occurring in the $3 \mathrm{hr}$ of recording, and the total time spent in seizures, which was determined by adding together the duration of all ictal episodes during the EEG recording period.

In pharmacological experiments, the EEG tracings from rats receiving the various drugs and those receiving kainic acid alone were compared visually. Shortly after administration, kainic acid induced stereotyped behaviors such as sniffing and gnawing. "Wet dog shakes" were often observed shortly after kainate and during seizures. These behaviors were not significantly affected by the treatments.

Because ictal events and spiking activity were in continuity in rats treated with bicuculline (Fig. $1 f, g$ ), we included both epileptic events when reckoning the total time in seizures $(69.6 \pm 12 \mathrm{~min} ; n=6)$. The onset time to the first epileptic event after bicuculline was $2.6 \pm 0.4 \mathrm{~min}$. Jumping and contralateral circling were induced in rats within the first 10 min after injection. Circling and wet dog shakes were often observed during EEG epileptic-like activity.

Schedule of treatment. Kainic acid $(0.19 \mathrm{nmol}$ in $0.5 \mu \mathrm{l})$ or bicuculline methiodide $(0.77 \mathrm{nmol}$ in $0.5 \mu \mathrm{l})$ (Sigma, St. Louis, MO) were dissolved in PBS (0.1 M, pH 7.4) or $12 \%$ polyethylene glycol (PEG 300; Bracco, Milan, Italy) in PBS, respectively. These were the lowest doses causing EEG seizures in $100 \%$ of the animals.

When assessing the effect of drugs on kainate-induced seizures, rats used as controls were injected with $0.5 \mu$ l of heat-inactivated (hr)IL-1 $\beta$
(1 ng; human recombinant IL- $1 \beta$ kindly provided by Dr. Diana Boraschi, Dompé, L'Aquila, Italy; bioactivity in murine thymocyte stimulation assay, $\left.\sim 3 \times 10^{7} \mathrm{U} / \mathrm{mg}\right) 10 \mathrm{~min}$ before kainic acid [0.04 $\mu \mathrm{g}(0.19 \mathrm{nmol})$ in $0.5 \mu 1$ of PBS]. Seizure activity (see Fig. 8, Table 1) did not significantly differ from that measured in rats injected with $0.5 \mu$ l of PBS before kainate. This excludes endotoxin contamination or unspecific effects on seizure activity attributable to the injection of a large molecule in the hippocampus. (hr)IL-1 $\beta$ was injected at doses ranging from $1 \mathrm{pg}$ to $1 \mathrm{ng}$ in $0.5 \mu \mathrm{l}$ at the same site as kainic acid $10 \mathrm{~min}$ before the convulsant. (hr)IL-1Ra (1 $\mu \mathrm{g}$; human recombinant IL-1Ra kindly provided by Dr. Diana Boraschi; inhibitory activity in murine thymocyte proliferation assay, $1.7 \times 10^{6} \mathrm{U} / \mathrm{mg}$ ), a naturally occurring antagonist of type I and type II IL-1 $\beta$ receptors (Eisenberg et al., 1990), was injected alone or together with IL-1 $\beta$ in $0.5 \mu \mathrm{l} 10 \mathrm{~min}$ before kainate. (3-((+)-2carboxypiperazin-4-yl)-propyl-1-phosphonate) [( $R)$-CPP; $0.1 \mathrm{ng}$ ], a selective competitive antagonist of NMDA receptors (Davies et al., 1986), was injected alone or co-injected with $1 \mathrm{ng}(\mathrm{hr}) \mathrm{IL}-1 \beta$ in $0.5 \mu \mathrm{l} 10 \mathrm{~min}$ before kainate. All drugs were injected over 1 min using a Hamilton syringe, and an additional minute elapsed before removal of the needle to avoid backflow of the drug through the cannula.

After the experiment, all rats treated with kainate and/or the various drugs were killed by decapitation, and their brains were extracted from the skull, rapidly frozen on dry ice, and sectioned using a cryostat (40 $\mu \mathrm{m})$ for visual inspection of the traces of the electrodes and the track of the injection needle. Rats treated with bicuculline were transcardially perfused as described below. The rats with the electrodes and/or the injection needle out of the hippocampus were excluded from this study.

Tissue preparation for immunocytochemistry. To assess the changes in the pattern of IL-1 $\beta$ immunoreactivity and for detecting microglia in the hippocampus, rats were injected with kainate or bicuculline methiodide, and their EEG was recorded for $3 \mathrm{hr}$ as described above $(n=5-8)$. 

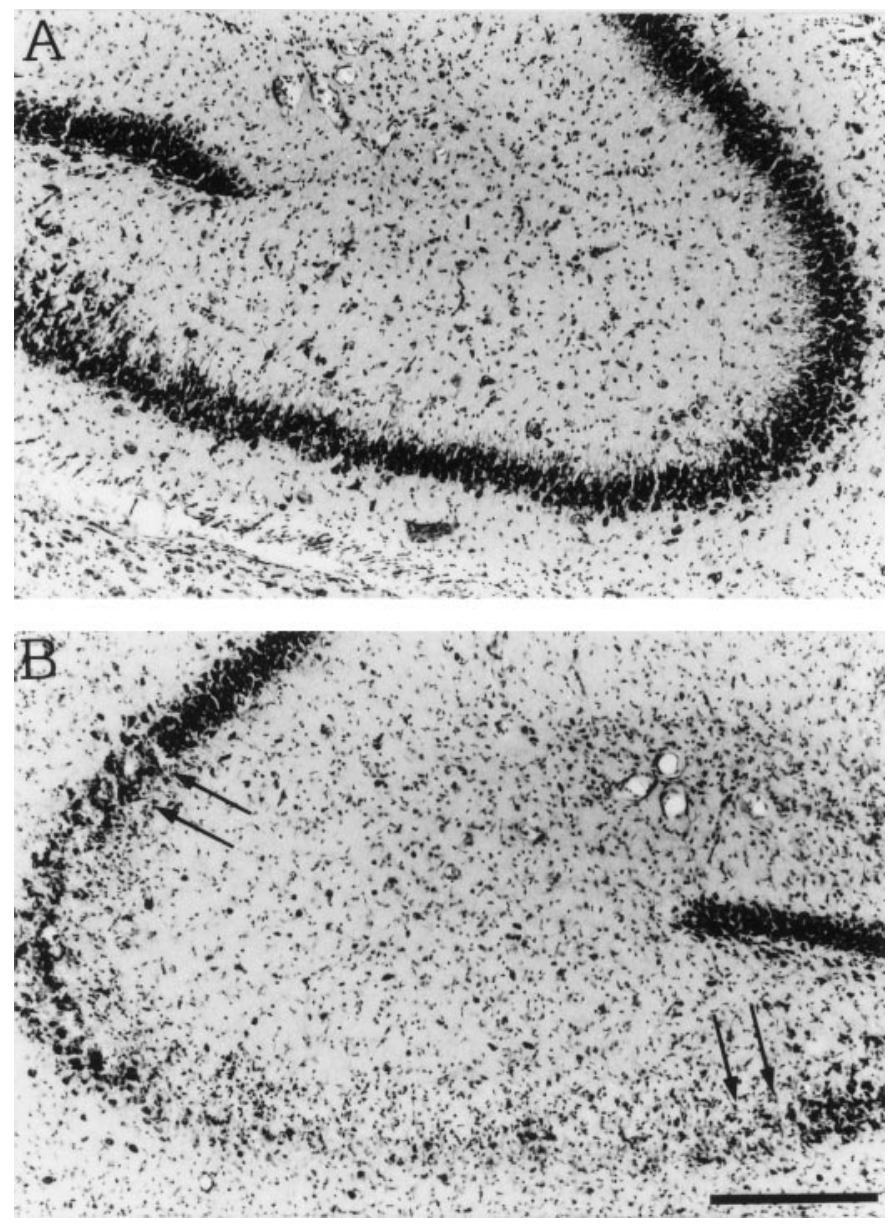

Figure 5. Nissl staining of coronal sections of the dorsal hippocampus of a representative rat 1 week after the injection of PBS $(A)$ or $0.19 \mathrm{nmol}$ of kainic acid $(B)$. Note the loss of CA3 neurons $(B$, arrows) that was restricted to the injected dorsal hippocampus. Scale bar, $200 \mu \mathrm{m}$.

For these experiments, kainate was injected in a group of rats different from that used for pharmacological studies. Controls ( $n=3$ each group) were rats implanted with the electrodes and injected with $0.5 \mu \mathrm{l}$ of vehicle. The rats and their respective controls were killed 3 and $24 \mathrm{hr}$ after injection.

Rats were deeply anesthetized with Equithesin and perfused via the ascending aorta with $250 \mathrm{ml} \mathrm{PBS}, 0.1 \mathrm{M}, \mathrm{pH} 7.4$, followed by $500 \mathrm{ml}$ of chilled paraformaldehyde (4\%) in PBS as previously described (Schwarzer et al., 1996). After carefully removing the brains from the skull, they were post-fixed in the same fixative as above for $90 \mathrm{~min}$ at $4^{\circ} \mathrm{C}$ and then transferred to $20 \%$ sucrose in PBS at $4^{\circ} \mathrm{C}$ for $24 \mathrm{hr}$ for cryoprotection. The brains were then rapidly frozen by immersion in isopentane at $-70^{\circ} \mathrm{C}$ for $3 \mathrm{~min}$ before being sealed into vials and stored at $-70^{\circ} \mathrm{C}$ until use.

Immunocytochemistry. Serial cryostat sections $(40 \mu \mathrm{m})$ were cut horizontally from all brains. The first and second sections of each series of five were collected for staining of IL- $1 \beta$, and adjacent sections were used for detection of Griffonia simplicifolia B4-isolectin (GSA I-B4) staining as a specific marker of microglia (Streit, 1990).

Briefly, free-floating sections were rinsed for $5 \mathrm{~min}$ in $0.4 \%$ Triton $\mathrm{X}-100$ in $50 \mathrm{~mm}$ Tris-HCl-buffered saline (TBS) at $4^{\circ} \mathrm{C}$ followed by 15 min in $20 \%$ methanol and $0.6 \% \mathrm{H}_{2} \mathrm{O}_{2}$ in Triton X-100-TBS. The slices were then incubated at $4{ }^{\circ} \mathrm{C}$ for $90 \mathrm{~min}$ in $10 \%$ fetal calf serum (FCS) diluted in $0.4 \%$ Triton X-100-TBS. The primary antisera were diluted in $0.4 \%$ Triton X-100-TBS containing $4 \%$ FCS, and slices were incubated at $4^{\circ} \mathrm{C}$ for $72 \mathrm{hr}$ with the primary polyclonal antibody against rat IL- $1 \beta$ (1:500; from Dr. S. Poole, National Institute for Biological Standards and Control, Potters Bar, Hertsfordshire, UK). This antibody recognizes both the pro-IL- $1 \beta$ and the mature proteins as assessed by Western blot (S. Pool, personal communication), and its cross-reactivity and specificity have been previously characterized in detail (Bristow et al., 1991; Gara- bedian et al., 1995). After three 5 min washes in TBS, immunoreactivity was tested by the avidin-biotin-peroxidase technique (Vectastain ABC kit; Vector Laboratories, Burlingame, CA). The sections were then reacted by incubation with $0.4 \mathrm{~mm} 3^{\prime}-3^{\prime}$-diaminobenzidine (DAB; Sigma,

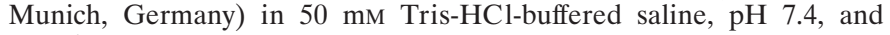
$0.01 \% \mathrm{H}_{2} \mathrm{O}_{2}$. After DAB incubation, three $5 \mathrm{~min}$ washes were done with TBS, and then the slices were mounted onto gelatin-coated slides and dried overnight at room temperature. They were dehydrated and coverslipped the next day.

Control slices were prepared using the primary antisera preadsorbed with (hr)IL-1 $\left(1 \mu \mathrm{M}, 24 \mathrm{hr}, 4^{\circ} \mathrm{C}\right)$ and by incubating the slices without the primary antisera.

For assessing microglia, the method described by Streit (1990) was followed. Briefly the sections were immersed in PBS, pH 7.4, for $10 \mathrm{~min}$. Slices were then incubated overnight at $4^{\circ} \mathrm{C}$ with GSA I-B4 isolectin coupled to HRP $(10 \mu \mathrm{g} / \mathrm{ml}$, Sigma) in PBS containing $0.1 \%$ Triton $\mathrm{X}-100,0.1 \mathrm{mM} \mathrm{CaCl} \mathrm{Cl}_{2}, 0.1 \mathrm{~mm} \mathrm{MgCl}{ }_{2}$, and $0.1 \mathrm{mM} \mathrm{MnCl}_{2}$. After the overnight incubation, the slices were washed three times for $5 \mathrm{~min}$ in PBS before a reaction with $\mathrm{DAB}$, which allows the lectin binding sites to be visualized.

Sections were taken at comparable anteroposterior and mediolateral levels in controls and epileptic rats. Nissl staining was performed with cresyl violet (Paxinos and Watson, 1986) in representative sections of controls and epileptic rats and in a distinct group of rats $(n=3-4)$ killed 1 week after convulsant injection to assess neurodegeneration.

ELISA. To quantify the increase in IL-1 $\beta$ depicted by immunocytochemistry, different groups of rats were intrahippocampally injected with $0.19 \mathrm{nmol}$ of kainate $(n=5)$ or $0.77 \mathrm{nmol}$ of bicuculline methiodide $(n=$ $8)$ as previously described.

Twenty four hours after injection, the rats and their controls (implanted with electrodes but injected with $0.5 \mu \mathrm{l}$ of vehicle; $n=6-8$ ) were killed by decapitation, and their hippocampi were rapidly dissected out at $4^{\circ} \mathrm{C}$ and frozen on dry ice. Brain tissue was weighted and homogenized in ice-cold PBS $(5 \mathrm{gm} / \mathrm{ml})$ using a Potter homogenizer (1000 rpm, 10 strokes). The homogenates were centrif uged for $10 \mathrm{~min}\left(5000 \mathrm{rpm}, 4^{\circ} \mathrm{C}\right)$. One hundred microliters of the supernatant were taken in duplicate to measure IL- $1 \beta$.

IL- $1 \beta$ was measured in the hippocampus by a two-site ELISA using an antibody selective against rat IL-1 $\beta$ (the same used for immunocytochemistry) as previously described (De Luigi et al., 1998). Absorbance was read at $405 \mathrm{~nm}$. The detection limit was $3.9 \mathrm{pg} / \mathrm{ml}$.

Statistical analysis of data. Data are the means \pm SE $(n=$ number of animals). The effects of treatments were analyzed by one-way or two-way ANOVA followed by Tukey's test for unconfounded means or by Student's $t$ test.

\section{RESULTS}

\section{Seizure-enhanced immunoreactivity of IL-1 $\beta$ in the rat hippocampus: comparison with activated microglia}

Figures 2 and 3 depict the pattern of IL- $1 \beta$ immunoreactivity in various areas of the injected dorsal hippocampus $3 \mathrm{hr}$ after kainic acid. IL- $1 \beta$ staining in control sections (from rats receiving $0.5 \mu \mathrm{l}$ of PBS) was diffused and barely detectable in glia-like cells throughout the dentate gyrus (Fig. 2A), CA1 (Fig. $3 A$ ), and CA3 (Fig. $3 E$ ) areas. Scattered, faintly stained neurons were observed in control sections of CA3 area (Fig. $3 E$ ) and in the granule cell layer (Fig. 4A). Seizures enhanced IL-1 $\beta$ immunoreactivity in all regions. Strongly immunoreactive glia-like cells were observed in the granule cells layer and in the hilus (Fig. 2C,E) as well as interposed between pyramidal neurons in CA1 (Fig. 3C) and CA3 (Fig. 3G) areas.

Activated microglia as defined by an ameboid shape and lectinpositive staining was similarly increased in adjacent sections (Figs. 2D,F, 3D, H). A few round-shaped, darkly stained cells resembling phagocytic cells were observed in the dentate gyrus and CA3 area (Figs. $2 F, 3 H$ ).

Figure 4 depicts the patterns of IL- $1 \beta$ staining (Fig. $4 A, C$ ) and that of activated microglia (Fig. 4B,D) $24 \mathrm{hr}$ after kainic acid in the injected hippocampus. IL- $1 \beta$-immunoreactive cells and microglia staining were enhanced in the various hippocampal areas 


\section{$\mathrm{IL}-1 \beta$}

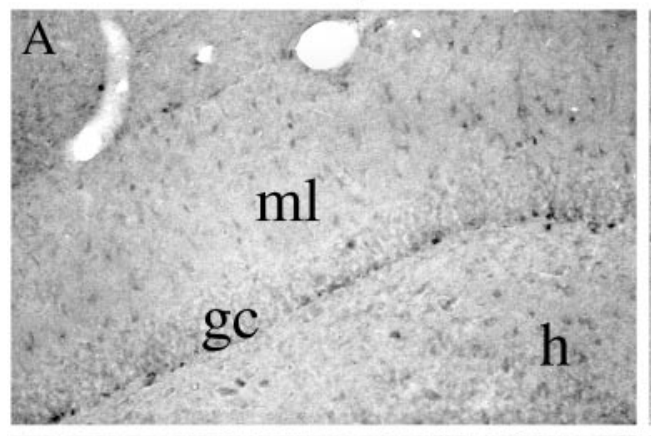

Figure 6. Photomicrographs showing IL-1 $\beta$ immunoreactivity $(A, C)$ and B4isolectin-positive microglia $(B, D)$ in coronal sections of the rat dorsal hippocampus $3 \mathrm{hr}$ after a local injection of $12.5 \%$ PEG $(A, B)$ or $0.77 \mathrm{nmol}$ of bicuculline methiodide $(C, D)$. IL-1 $\beta$ immunoreactivity was markedly increased in glia-like cells located in the granule cell layer and in the molecular layer $(\mathrm{ml})$ of the dentate gyrus (arrowheads). These cells have a darkly stained cell body and branched processes. Some of these cells were in close proximity to granule cells $(g c)$ and interposed between $\mathrm{CA} 3 \mathrm{c}$ neurons in the hilus $(h ; C$, arrowheads). B4-isolectin-positive microglia was increased in the same regions (D). Scale bar, $200 \mu \mathrm{m}$.

with a more diff use pattern compared with the clusters of heavily stained IL- $1 \beta$-positive cells and microglia found $3 \mathrm{hr}$ after seizures.

Similar changes were found in the temporal pole of the injected hippocampus. A small increase in IL- $1 \beta$ and microglia staining restricted to stratum radiatum CA3 was observed in the contralateral hippocampus at both time points (results not shown).

Nissl staining of coronal sections from rats killed 1 week after kainate-induced seizures showed the typical pyramidal cell loss restricted to CA3 area as previously reported (Vezzani et al., 1991) (Fig. 5).

Rats were injected intrahippocampally with a previously described nonlesional convulsant dose of bicuculline methiodide (Turski et al., 1985) to investigate whether seizures per se, in the absence of cell injury, induced IL- $1 \beta$ and microglia in the hippocampus. Nissl staining performed in coronal brain sections of rats killed 1 week after bicuculline-induced seizures $(n=4)$ confirmed the lack of neurodegeneration. Thus, the injected and contralateral hippocampi did not differ from vehicle-injected rats as assessed by light microscopic analysis (results not shown).

Figures 6 and 7 show the pattern of IL-1 $\beta$ immunoreactivity and activated microglia in the dentate gyrus (Fig. 6A-D) and hippocampus proper (Fig. $7 A-H) 3 \mathrm{hr}$ after bicuculline injection. IL-1 $\beta$ immunoreactivity was enhanced in all hippocampal subfields compared with vehicle-injected rats, although to a less extent in CA1 and CA3 areas than in kainate-treated rats. Thus, few strongly immunoreactive glial cells were present in CA1 after bicuculline (compare Figs. $7 C, 3 C$ ). Darkly stained IL- $1 \beta$-positive cells were absent in $\mathrm{CA} 3$, whereas a diffused pattern of faintly stained cells was observed there (compare Figs. $7 G, 3 G$ ). The changes detected after bicuculline were more pronounced in the injected hippocampus, although they also occurred in the contralateral site and in the temporal poles as observed after kainate injection (results not shown). Twenty four hours after bicuculline-induced seizures, IL-1 $\beta$ immunoreactivity was very similar to that in vehicle-injected rats, as confirmed by measuring its tissue concentration by ELISA (see below).

\section{MICROGLIA}

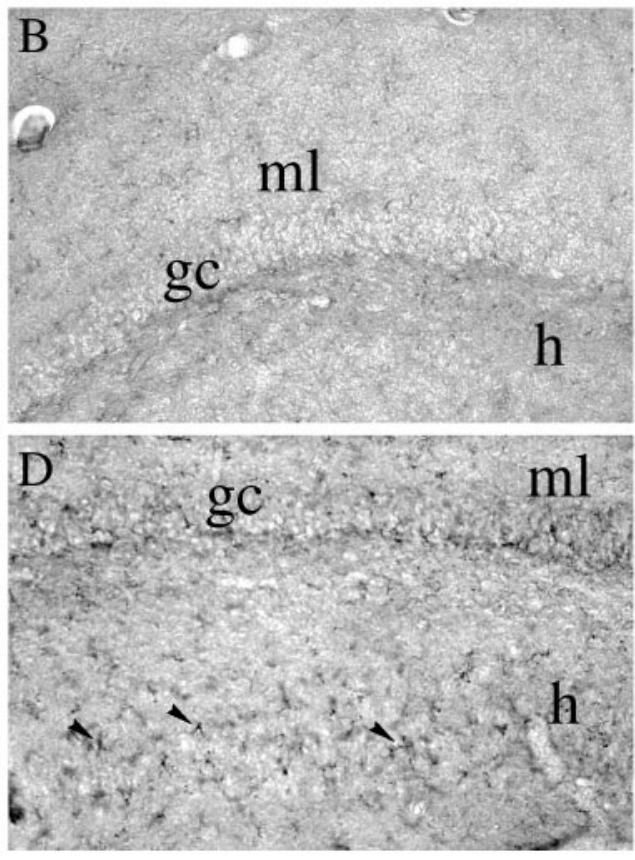

The pattern of activated microglia after bicuculline was similar to that observed after kainate, although cells were less intensively stained in all hippocampal subfields (Figs. 6B,D 7B,D,F,H).

\section{ELISA}

Using ELISA, an average 16 -fold increase in IL- $1 \beta$ concentration was measured in the injected hippocampus $24 \mathrm{hr}$ after kainic acid compared with PBS-injected rats $[\mathrm{pg} / \mathrm{mg}$ wet weight tissue: PBS, $1.55 \pm 0.15(n=6)$; kainate, $24.2 \pm 8.4^{*}(n=5) ;{ }^{*} p<0.01$ by Student's $t$ test]. In accordance with the immunocytochemical evidence, a small increase (30\%) was also measured in the hippocampus contralateral to the injected site $(2.64 \pm 1.0 \mathrm{pg} / \mathrm{mg})$, although this effect was not statistically significant.

Twenty four hours after bicuculline, no significant differences were found in the injected $[\mathrm{pg} / \mathrm{mg}$ wet weight tissue: $\mathrm{PEG}, 1.8 \pm$ $0.5(n=8)$; bicuculline, $2.9 \pm 1.2]$ or contralateral hippocampus (bicuculline, $1.24 \pm 0.3 \mathrm{pg} / \mathrm{mg}$ ).

\section{Effect of IL-1 $\beta$ and/or IL-1Ra on kainic acid-induced EEG seizures}

Figure 8 shows the effect of 0.1 and $1.0 \mathrm{ng}$ of (hr)IL- $1 \beta$ and/or 1.0 $\mu \mathrm{g}$ of IL-1Ra on EEG seizure activity induced by $0.19 \mathrm{nmol}$ of kainic acid in rats. The intrahippocampal injection of $0.1 \mathrm{ng}$ of (hr)IL1- $\beta 10$ min before kainate was ineffective on seizure parameters, whereas $1.0 \mathrm{ng}$ of (hr)IL-1 $\beta$ increased by 2.3 -fold on average the time spent in kainate seizures $(p<0.01$, one-way ANOVA followed by Tukey's test), and this effect was similar to that observed after $10 \mathrm{ng}$ of (hr)IL-1 $\beta$ (data not shown). Interictal activity consisting of high-frequency spiking synchronized in both hippocampi was observed in the second hour of EEG recording after (hr)IL-1 $\beta$ plus kainic acid. (hr)IL- $1 \beta$ did not significantly modify the time to onset of seizures $(10.8 \pm 1.4 \mathrm{~min}$; $n=21)$ and the number of seizures $(15.0 \pm 1.0)$. Heat-inactivated (hr)IL-1 $\beta$ up to $1 \mathrm{ng}$ did not modify seizures $(n=10)$.

To assess whether the effect of IL-1 $\beta$ on seizures was receptormediated, we injected the animals with $1 \mu \mathrm{g}$ of (hr)IL-1Ra (Eisenberg et al., 1990). It has been previously reported that 
IL-1 $\beta$
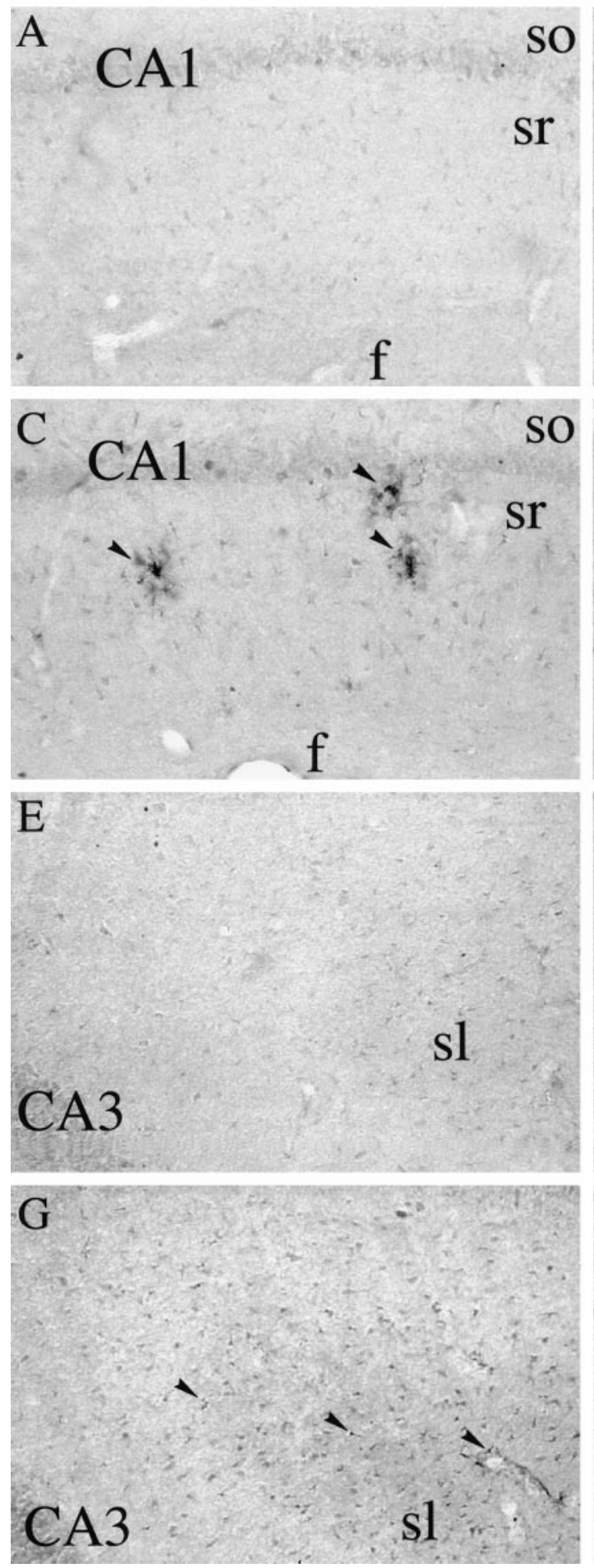

MICROGLIA
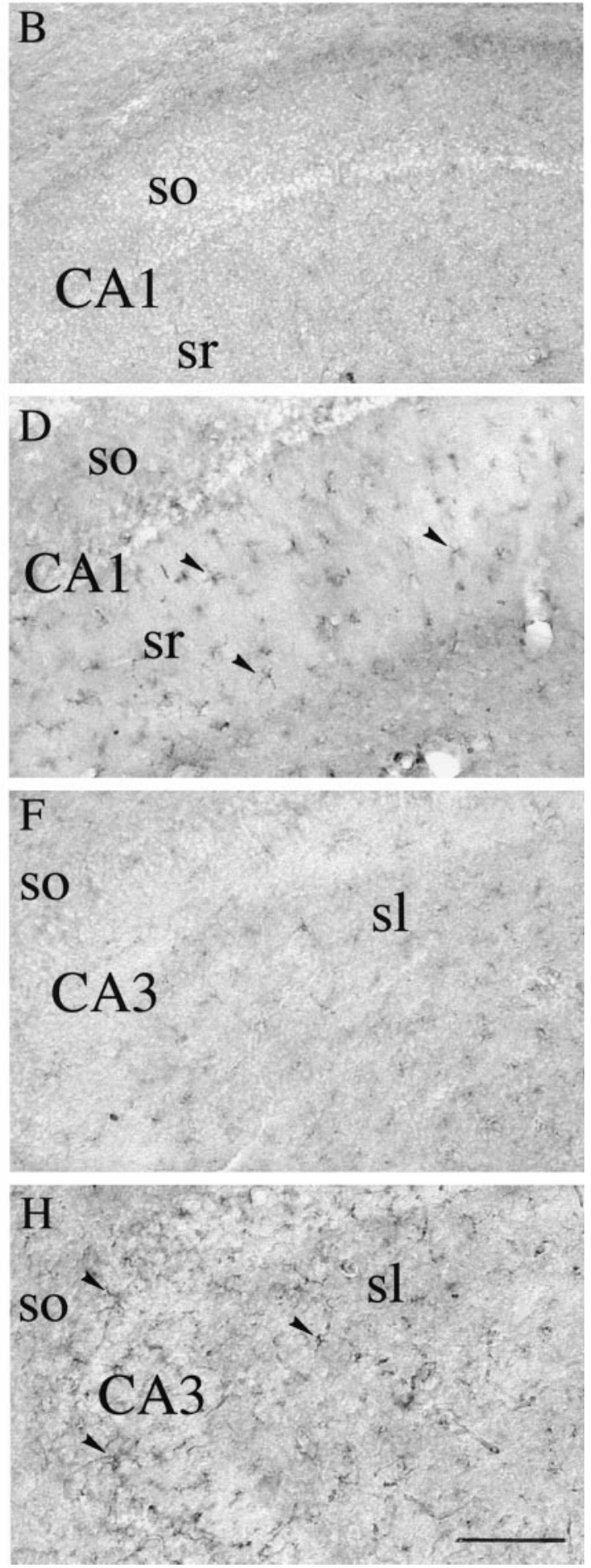

Figure 7. High-magnification photomicrographs showing IL- $1 \beta$ immunoreactivity $(A, C, E, G)$ and B4-isolectin-positive microglia $(B, D, F, H)$ in coronal sections of the CA1 $(A-D)$ and CA3 $(E-H)$ areas of the rat dorsal hippocampus $3 \mathrm{hr}$ after a local injection of $12.5 \%$ PEG $(A, B, E, F)$ or 0.77 nmol of bicuculline methiodide in PEG $(C, D, G, H)$. IL-1 $\beta$ immunoreactivity was enhanced in darkly stained cells with ramified processes in stratum radiatum $(s r)$ of CA1 pyramidal layer $(C$, arrowheads). A diff use pattern of lightly stained cells was observed in CA3 ( $G$, arrowheads). B4-isolectin-positive microglia was enhanced in stratum radiatum $(s r)$ CA1 $(D$, arrowheads) and in stratum lucidum $(s l)$ CA3 ( $H$, arrowheads). Microglia processes were interposed between pyramidal cells in CA3. $f$, Fissura hippocampi; so, stratum oriens. Scale bar, $200 \mu \mathrm{m}$. 


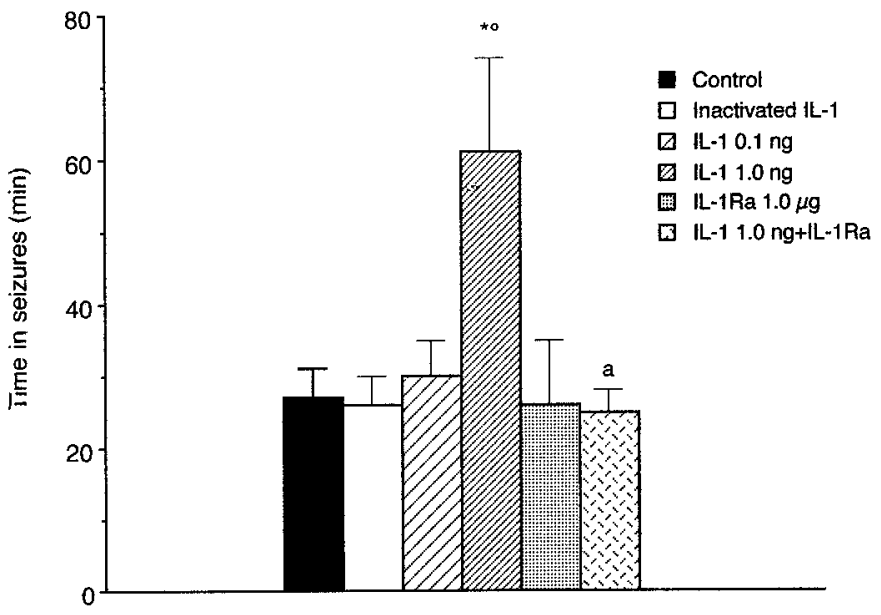

Figure 8. Bar graph showing the effect of IL-1 $\beta$ and/or IL-1Ra on the time spent in EEG seizures in rats treated with kainic acid. Control $(n=$ 21) represents rats receiving $0.5 \mu \mathrm{l}$ of PBS $10 \mathrm{~min}$ before $0.19 \mathrm{nmol}$ in 0.5 $\mu \mathrm{l}$ of kainic acid. (hr)IL-1 $\beta(n=10)$ was heat-inactivated by boiling the solution for $15 \mathrm{~min}$. Drugs were unilaterally injected in the hippocampus in $0.5 \mu$ alone $(n=7-11)$ or in combination $(n=9) 10 \mathrm{~min}$ before kainic acid. Seizure activity was recorded in freely moving rats for $3 \mathrm{hr}$ from drug injection. ${ }^{\mathrm{a}} F_{(1,51)}=8.6 ; p<0.01$ by two-way ANOVA followed by Tukey's test for uncounfounded means; ${ }^{*} p<0.01$ versus control; ${ }^{\circ} p<0.01$ versus heat-inactivated IL-1 $\beta$.

doses of IL-1Ra $10^{2}$ - to $10^{3}$-fold higher than those of IL-1 $\beta$ are needed to block the functional effects of this cytokine (Arend et al., 1990). This likely depends on the fact that only a few IL-1 receptors need to be stimulated to trigger a biological response; thus high levels of IL-1Ra are necessary for blocking unoccupied receptors (Rothwell, 1991). (hr)IL-1Ra per se $(n=8)$ did not affect the baseline EEG pattern but when co-injected with $1 \mathrm{ng}$ of (hr)IL-1 $\beta$ blocked the proconvulsant effect of this cytokine $(n=$ $8)$. Thus, the 2.3 -fold increase in the total time in seizures induced by $1.0 \mathrm{ng}$ of (hr)IL-1 $\beta$ was abolished in the presence of the antagonist $\left(F_{(1,51)}=8.6 ; p<0.01\right.$, two-way ANOVA) (Fig. 6). Heat-inactivated (hr)IL-1Ra did not modify the effect of $1 \mathrm{ng}$ of (hr)IL-1 $\beta$ on kainate seizures (data not shown).

\section{Effect of $(R)$-CPP on the proconvulsant effect of IL-1 $\beta$}

Table 1 shows the effect of $(R)$-CPP on the proconvulsant action of (hr)IL- $1 \beta$ on kainate seizures $(n=7)$. $(R)$-CPP at $0.1 \mathrm{ng}$, a dose previously shown to block NMDA-induced behavioral seizures in rodents (Davies et al., 1986), co-administered with $1 \mathrm{ng}$ of IL- $1 \beta$ abolished the twofold increase induced by this cytokine in the total time spent in kainate seizures $\left(n=9 ; F_{(1,30)}=7.6 ; p<\right.$ 0.01 by two-way ANOVA) without having an effect per se $(n=8)$. The onset time to seizures and the total number of seizures measured in rats treated with kainic acid $(n=26)$ were not significantly modified by $1 \mathrm{ng}$ of (hr)IL-1 $\beta(n=8)$ and/or $0.1 \mathrm{ng}$ of $(R)$-CPP. Selective blockade of NMDA receptors by $(R)$-CPP did not affect EEG seizures induced by kainic acid per se, as previously reported (Lason et al., 1988; Clifford et al., 1990).

\section{DISCUSSION}

In the present study, we provide direct evidence that focal intrahippocampal application of kainic acid in rats inducing EEG seizures and CA3 neuronal damage is associated with a rapid increase in the levels of IL- $1 \beta$ in the hippocampus presumably in activated microglia cells.

The early induction of IL- $1 \beta$ induced by kainate injection is in accordance with the rapid upregulation of its mRNA after seizure-producing agents (Minami et al., 1990, 1991; Yabuuchi et al., 1993) and with previous evidence showing that the mature form of IL- $1 \beta$ increases as early as $4 \mathrm{hr}$ after intracerebral injection of NMDA in newborn rats (Hagan et al., 1996).

The finding that IL- $1 \beta$ immunoreactivity is enhanced in glial cells resembling activated microglia agrees with the evidence that IL- $1 \beta$ mRNA expression induced by systemic kainic acid is localized in glial cells not expressing glial fibrillary acidic protein, a selective marker of astrocytes (Yabuuchi et al., 1993). In addition, recent studies by Andersson et al. (1991) and Taniwaki et al. (1996) have shown that kainate administration activates microglia in brain structures involved in the propagation pathways of hippocampal seizures and closely associated with seizure-induced neuronal damage.

Using bicuculline as a nonlesional model of seizures, we found that both IL- $1 \beta$ and microglia were enhanced in the hippocampus. These changes were induced to a lesser extent and for a shorter duration than after kainate, although the time spent in EEG epileptic activity after bicuculline was longer.

These findings show that direct stimulation of the kainate-type of glutamate receptors is not a prerequisite for increasing IL- $1 \beta$ in glia and that seizure activity per se is sufficient to trigger this effect. Thus, we found no histological evidence of neuronal cells loss in the hippocampus after the relatively low convulsant dose of bicuculline we have used (also see Turski et al., 1985).

The contribution of neuronal cell injury in CA3 pyramidal layer to the enhanced cytokine response to kainate cannot be solved in the present study. However, various evidence suggests that degenerating neurons represent a strong signal for IL-1 $\beta$

Table 1. Effect of $(R)$-CPP on the IL-1 $\beta$-induced potentiation of seizure activity caused by $0.19 \mathrm{nmol}$ of kainic acid injected in the rat hippocampus

\begin{tabular}{lccll} 
Drug & Dose $(\mathrm{ng})$ & Onset $(\mathrm{min})$ & No. of seizures & Time in seizures (min) \\
\hline Control & & $11.3 \pm 2.0$ & $15.0 \pm 1.0$ & $26.3 \pm 1.8$ \\
IL-1 $\beta$ & 1.0 & $12.3 \pm 2.9$ & $16.0 \pm 1.0$ & $52.3 \pm 4.9^{*}$ \\
$(R)$-CPP & 0.1 & $8.5 \pm 1.9$ & $16.0 \pm 2.0$ & $26.8 \pm 3.3$ \\
IL-1 $\beta+(R)$-CPP & & $8.5 \pm 1.9$ & $16.0 \pm 3.0$ & $27.0 \pm 5.0^{* * * * * *}$
\end{tabular}

Data are the means $\pm \mathrm{SE}(n=8-26)$. Control $(n=26)$ were rats receiving heat-inactivated (hr)IL-1 $\beta(1.0 \mathrm{ng}$ in $0.5 \mu \mathrm{l}) 10$ min before $0.19 \mathrm{nmol}$ in $0.5 \mu \mathrm{l}$ of kainic acid. Drugs were unilaterally injected in the hippocampus in $0.5 \mu \mathrm{l} 10 \mathrm{~min}$ before kainic acid. $(R)$-CPP $(n=8)$ were rats co-injected with heat-inactivated (hr)IL-1 $\beta$ before kainic acid. Seizure activity was recorded in freely moving rats for $3 \mathrm{hr}$ from drug injection.

${ }^{*} p<0.01$ versus control.

${ }^{* *} F_{(1,30)}=7.6(n=9) ; p<0.01$ by two-way ANOVA followed by Tukey's test for unconfounded means.

$* * * P<0.01$ versus IL-1 $\beta$. 
induction (Rothwell, 1991), and microglial cells are known to be rapidly activated in response to even minor pathological changes in CNS (Kreutzberg, 1996).

The widespread pattern of increased IL $-1 \beta$ immunoreactivity observed after focal injection of kainate may depend on different factors or by their concerted action: i.e., it is known that IL- $1 \beta$ induces its own synthesis (Dinarello et al., 1987), and this positive feedback loop may contribute to enhance and extend the IL-1 response; mild inflammatory or edemic responses may occur in distant sites because of their direct connections to the injured hippocampus and may trigger IL $-1 \beta$ production; the propagation of epileptic activity from its site of onset to synaptically connected tissue (i.e., the contralateral site and the temporal pole of the hippocampus) may trigger IL- $1 \beta$ production per se, as suggested by our findings after bicuculline seizures.

The mechanisms by which seizure activity per se may induce IL- $1 \beta$ in the resident glial cells are unknown. Protein extravasation in the brain parenchima caused by blood-brain barrier breakdown during seizures (Nitsch et al., 1986) and/or ionic changes induced by seizures in the extracellular environment and in glial cells (Barres, 1991) may prime glia to synthesize higher amounts of cytokines.

In an attempt to address the functional role of this inflammatory cytokine in seizures, we found that exogenously applied (hr)IL-1 $\beta$ enhanced EEG seizure activity induced by kainic acid in a dose-dependent and receptor-mediated manner. EEG seizures induced by focal kainate injection were not associated with behavioral convulsions, and the increase in focal EEG seizure duration induced by IL- $1 \beta$ had no impact on rat behavior.

The action of IL-1 $\beta$ involves an increase in or facilitation of glutamatergic function through the NMDA receptors, because the enhancing effect on seizures was blocked by a selective NMDA receptor antagonist. Blockade of IL- $1 \beta$ effect by IL-1Ra or $(R)$-CPP excludes that this cytokine affects seizures by merely delaying kainic acid elimination from the tissue.

The lack of effect of IL- $1 \beta$ on the onset time to seizures may be related to its inability to interfere with the mechanisms involved in seizure induction (Westbrook and Lothman, 1983), although it is specifically effective on the events that are crucial for seizure maintenance. In this respect, the evidence that IL- $1 \beta$ increases extracellular glutamate availability (Ye and Sontheimer, 1996; Mascarucci et al., 1998) and interacts with NMDA receptor function (as shown by our pharmacological findings) is consistent with its effect of prolonging the time spent in seizures. Thus, both synaptic and intrinsic conductance properties of neurons are known to be involved in sustaining synchronized afterdischarges in the hippocampus (Traub et al., 1993). The specific effect of IL- $1 \beta$ on the duration of seizures conforms our previous evidence showing that the onset, number, and duration of EEG seizures can be independently affected by drugs (Vezzani et al., 1986, 1991; Gariboldi et al., 1998).

These results are apparently at variance with the electrophysiological evidence showing that IL- $1 \beta$ has inhibitory effects on long-term potentiation (Katsuki et al., 1990; Bellinger et al., 1993; Cunningham et al., 1996; Coogan and O'Connor, 1997), and it augments the GABA-mediated increase in chloride permeability in cortical synaptoneurosomes (Miller et al., 1991). However, in vitro and in vivo evidence suggests that the effects of IL- $1 \beta$ on neurons depend on several factors, including the functional state of the neurons (healthy or injured), the timing of cytokine release, the duration of tissue exposure, and the concentration of the cytokine (Rothwell and Hopkins, 1995). In particular, rela- tively low amounts of IL-1 $\beta$ (picomolar or low nanomolar range) inhibit neuronal activity and support neuronal survival (Rothwell, 1991; Morganti-Kossmann et al., 1992), whereas concentrations of IL-1 $\beta$ similar to those used in the present study or higher have deleterious effects on neuron viability (Rothwell, 1991; MorgantiKossmann et al., 1992). Interestingly, the functional effects of IL- $1 \beta$ also depend on the brain region examined. Thus, the ability of this cytokine to modify excitotoxic brain damage in rats differs between striatum and cortex (Lawrence et al., 1998), and even relatively low doses of IL-1 $\beta$ ( $0.5 \mathrm{nM})$ consistently decrease synaptic inhibition by $\sim 30 \%$ in CA3 pyramidal cells (Zeise et al., 1997).

With regard to the mechanism involved in the facilitation of glutamatergic neurotransmission that appears to mediate the enhancing effect of IL- $1 \beta$ on kainate-induced EEG seizures, it remains to be established whether this is secondary to an altered pattern of neuronal damage (i.e., kainate seizures may be prolonged by IL-1 $\beta$ promoting damage, which results in higher glutamate release). In this respect, exogenously applied IL-1 $\beta$ exacerbates excitotoxic neuronal damage and edema induced by ischemia (Yamasaki et al., 1995; Loddick and Rothwell, 1996) as well as the neurodegeneration induced in the cortex by activation of the NMDA and AMPA subtypes of glutamate receptors (Lawrence et al., 1998).

IL-1 $\beta$, however, may increase glutamate neurotransmission also by mechanisms independent of neuronal cell injury. Thus, IL-1 $\beta$ markedly attenuates astrocytic glutamate uptake (Ye and Sontheimer, 1996). This effect may enhance the extracellular glutamate concentration and may synergize with the increased glutamate release induced by kainate (Ferkany and Coyle, 1983; Young et al., 1988). IL-1 $\beta$ may also directly enhance NMDA receptor function, because IL- $1 \beta$ receptors are associated with signal transduction pathways (i.e., activation of Ser-Thr protein kinase (PK), PKA, and PKC and generation of nitric oxide), which are known to affect the response of NMDA receptors to endogenous ligands (Hewett et al., 1994; Hollman and Heinemann, 1994; Schobitz et al., 1994).

Finally, the effect of IL-1 $\beta$ may involve other cytokines as well. Thus, IL- 1 induces the synthesis of IL- 6 and TNF- $\alpha$ in astrocytes and microglia (Bartfai and Schultzberg, 1993; Schobitz et al., 1994), and many actions of IL-1 in CNS are mediated by these cytokines (Rothwell, 1991). IL-6 and TNF- $\alpha$, in turn, have been reported to affect synaptic transmission (Tancredi et al., 1992; Schobitz et al., 1994; Li et al., 1997), and mice overexpressing IL-6 and TNF in glia develop both seizures and neurodegeneration (Campbell et al., 1993; Akassoglou et al., 1997).

The local administration of $0.1-1 \mu \mathrm{M}$ (hr)IL-1 $\beta$ in the rat hippocampus has been shown to increase the body temperature after $2-4 \mathrm{hr}$ of continuous infusion. This increase was $2^{\circ} \mathrm{C}$ on average above physiological values (Linthorst et al., 1994) and was likely mediated by the hypothalamus, because there are reciprocal connections between the hippocampus and various hypothalamic areas (Amaral and Witter, 1995). However, it is unlikely that the increase in body temperature plays a role in the effect of IL- $1 \beta$, because values as high as $42^{\circ} \mathrm{C}$ are needed to enhance EEG seizure activity induced by kainic acid in rats (Liu et al., 1993).

IL-1Ra alone did not affect kainic acid-induced seizures after its focal application in the hippocampus. Doses of $>1 \mu \mathrm{g}$ could not be tested in our model because of the limit of solubility of this molecule in the small volume required by intrahippocampal administration. We have recent evidence, however, that repeated intraventricular injection of $0.1 \mu \mathrm{g}$ of IL-1Ra significantly re- 
duced EEG seizures caused by intrahippocampal kainate (our unpublished data). Intraventricular injection of IL-1Ra may block more effectively the action of endogenously produced IL- $1 \beta$ because of the widespread pattern of induction of IL- $1 \beta$ not solely restricted to the site of intrahippocampal IL-1Ra injection. These findings support a functional role of IL- $1 \beta$ endogenously produced after kainate.

IL-1 is known to upregulate the expression of neurotrophic factors such as nerve growth factor and brain-derived neurotrophic factor (Spranger et al., 1990; Lapchak et al., 1993) and neuropeptides such as somatostatin (Scarborough et al., 1989) that are significantly involved in seizure modulation (Schwarzer et al., 1996; Scharfman, 1997). These events, however, require a time window not compatible with the early action of IL- $1 \beta$ in our models of acute seizures. They may represent long-term effects of this cytokine and possibly play a functional role in the chronic changes in neurotransmission induced in brain tissue by an acute epileptic event (M. G. De Simoni, C. Perego, T. Ravizza, D. Moneta, M. Conti, S. Garattini, and A. Vezzani, unpublished results).

Thus, convulsant and/or excitotoxic stimuli increase the production of IL-1 $\beta$ in microglia-like cells in the hippocampus. In addition, our pharmacological findings indicate that IL-1 $\beta$ enhances focal electrographic seizures induced by kainate through an increase in glutamatergic neurotransmission. Increased production of IL-1 has been shown in human temporal lobe epilepsy (Sheng et al., 1994), thus suggesting that this cytokine may play a role in the neuropathology of the epileptic tissue.

\section{REFERENCES}

Akassoglou K, Probert L, Kontogeorgos G, Kollias G (1997) Astrocytespecific but not neuron-specific transmembrane TNF triggers inflammation and degeneration in the central nervous system of transgenic mice. J Immunol 158:438-445.

Amaral DG, Witter MP (1995) Hippocampal formation. In: Hippocampus (Paxinos G, ed), pp 443-493. San Diego: Academic.

Andersson PB, Perry VH, Gordon S (1991) The kinetics and morphological characteristics of the macrophage-microglial response to kainic acid-induced neuronal degeneration. Neuroscience 42:201-214.

Arend WP, Welgus HG, Thompson RC, Eisenberg SP (1990) Biological properties of recombinant human monocyte-derived interleukin-1 receptor antagonist. J Clin Invest 85:580-583.

Ban E, Milon G, Fillion G, Haour F (1991) Receptors for interleukin-1 $(\alpha$ and $\beta)$ in mouse brain: mapping and neuronal localization in hippocampus. Neuroscience 43:21-30.

Barres BA (1991) New roles for glia. J Neurosci 11:3685-3694.

Bartfai T, Schultzberg M (1993) Cytokines in neuronal cell types. Neurochem Int 22:435-444.

Bellinger FP, Madamba S, Siggins GR (1993) Interleukin $1 \beta$ inhibits synaptic strength and long-term potentiation in the rat CA1 hippocampus. Brain Res 628:227-234.

Benveniste EN (1992) Inflammatory cytokines within the central nervous system: sources, function and mechanism of action. Am J Physiol 263:C1-C16.

Bristow AF, Mosley K, Poole S (1991) Interleukin-1 $\beta$ production in vivo and in vitro in rats and mice measured using specific immunoradiometric assays. J Mol Endocrinol 7:1-7.

Campbell IL, Abraham CR, Masliah E, Kemper P, Inglis JD, Oldstone MBA, Mucke L (1993) Neurological disease induced in transgenic mice by cerebral overexpression of interleukin 6. Proc Natl Acad Sci USA 90:10061-10065.

Clifford DB, Olney JW, Benz AM, Fuller TA, Zorumski CF (1990) Ketamine, phencyclidine and MK-801 protect against kainic acidinduced seizure-related brain damage. Epilepsia 31:382-390.

Coogan A, O'Connor JJ (1997) Inhibition of NMDA receptor-mediated synaptic transmission in the rat dentate gyrus in vitro by IL- $1 \beta$. NeuroReport 8:2107-2110.

Cunningham AJ, Murray CA, O’Neill LAJ, Lynch MA, O'Connor JJ (1996) Interleukin-1 $\beta$ (IL-1 $\beta$ ) and tumor necrosis factor (TNF) inhibit long-term potentiation in the rat dentate gyrus in vitro. Neurosci Lett 203:17-20.

Curtis DR, Duggan AW, Felix D, Johnston GA (1970) GABA, bicuculline and central inhibition. Nature 226:1222-1224.

D’Arcangelo G, Dodt H, Zieglgansberger W (1997) Reduction of excitation by interleukin- $1 \beta$ in rat neocortical slices visualized using infrared-darkfield video microscopy. NeuroReport 8:2079-2083.

Davies J, Evans RH, Herrling PL, Jones AW, Olverman HJ, Pook P, Watkins JC (1986) CPP, a new potent NMDA antagonist. Depression of central neuron responses, affinity for $\left({ }^{3} \mathrm{H}\right) \mathrm{D}$-AP5 binding sites on brain membranes and anticonvulsant activity. Brain Res 382:169-173.

de Bock F, Dornand J, Rondouin G (1996) Release of TNF $\alpha$ in the rat hippocampus following epileptic seizures and excitotoxic neuronal damage. NeuroReport 7:1125-1129.

De Luigi A, Terreni L, Sironi M, De Simoni MG (1998) The sympathetic nervous system tonically inhibits peripheral IL- $1 \beta$ and IL-6 induction by central lipopolysaccharide. Neuroscience 83:1245-1250.

De Simoni MG, Imeri L (1998) Cytokine-neurotrasmitter interactions in the brain. Biol Signals 7:33-44.

Dinarello CA, Ikejima T, Warner SJ, Orencole SF, Lonnemann G, Cannon JG, Libby P (1987) Interleukin-1. I. Induction of circulating interleukin-1 in rabbits in vivo and in human mononuclear cells in vitro. J Immunol 139:1902-1906.

Eisenberg SP, Evans RJ, Arend WP, Verber E, Brewer MT, Hannun CH, Thompson RC (1990) Primary structure and functional expression from complementary DNA of a human interleukin-1 receptor antagonist. Nature 343:341-346.

Eriksson C, Winblad B, Schltzberg M (1998) Kainic acid induced expression of interleukin-1 receptor antagonist mRNA in the rat brain. Mol Brain Res 58:195-208.

Ferkany J, Coyle JT (1983) Kainic acid selectively stimulates the release of endogenous excitatory acidic amino acids. J Pharmacol Exp Ther 225:399-406.

Garabedian BS, Poole S, Allchorne A, Winter J, Woolf C (1995) Contribution of interleukin- $1 \beta$ to the inflammation-induced increase in nerve growth factor levels and inflammatory hyperalgesia. Br J Pharmacol 115:1265-1275.

Gariboldi M, Conti M, Cavaleri D, Samanin R, Vezzani A (1998) Anticonvulsant properties of BIBP 3226, a non-peptide selective antagonist at neuropeptide Y Y-1 receptors. Eur J Neurosci 10:757-759.

Giulian D, Baker TJ, Shih LC, Lachman LB (1986) Interleukin-1 in the central nervous system is produced by ameboid microglia. J Exp Med 164:594-604.

Hagan P, Poole S, Bristow AF, Tilders F, Siverstein FS (1996) Intracerebral NMDA injection stimulates production of interleukin- $1 \beta$ in perinatal rat brain. J Neurochem 67:2215-2218.

Hewett SJ, Csernansky CA, Choi DW (1994) Selective potentiation of NMDA-induced neuronal injury following induction of astrocytic iNOS. Neuron 13:487-494.

Hollmann M, Heinemann S (1994) Cloned glutamate receptors. In: Annual review of neuroscience (Cowan MW, Shooter EM, Stevens CF, Thompson RF, eds), pp 31-108. Palo Alto, CA: Annal Reviews.

Hopkins SJ, Rothwell NJ (1995) Cytokine and the nervous system I: expression and recognition. Trends Neurosci 18:83-88.

Katsuki H, Nakai S, Hirai Y, Akaji K, Kiso Y, Satoh M (1990) Interleukin- $1 \beta$ inhibits long-term potentiation in the CA3 region of mouse hippocampal slices. Eur J Pharmacol 181:323-326.

Kreutzberg GW (1996) Microglia: a sensor for pathological events in the CNS. Trends Neurosci 19:312-318.

Lapchak PA, Araujo DM, Hefti F (1993) Systemic interleukin-1 $\beta$ decreases brain-derived neurotrophic factor messenger RNA expression in the rat hippocampal formation. Neuroscience 53:297-301.

Lason W, Simpson JN, McGinty JF (1988) Effects of D-(-)aminophosphonovalerate on behavioral and histological changes induced by systemic kainic acid. Neurosci Lett 87:23-28.

Lawrence CB, Allan SM, Rothwell NJ (1998) Interleukin-1 $\beta$ and the interleukin-1 receptor antagonist act in the striatum to modify excitotoxic brain damage in the rat. Eur J Neurosci 10:1188-1195.

Li A-J, Katafuchi T, Oda S, Hori T, Oomura Y (1997) Interleukin-6 inhibits long-term potentiation in rat hippocampal slices. Brain Res 748:30-38.

Linthorst ACE, Flachskam C, Holsboer F, Reul JMHM (1994) Local administration of recombinant human interleukin- $1 \beta$ in the rat hippocampus increases serotonergic neurotransmission, hypothalamic- 
pituitary-adrenocortical axis activity, and body temperature. Endocrinology 135:520-532.

Liu Z, Gatt A, Mikati M, Holmes GL (1993) Effect of temperature on kainic acid-induced seizures. Brain Res 631:51-58.

Loddick SA, Rothwell NJ (1996) Neuroprotective effects of human recombinant interleukin-1 receptor antagonist in focal cerebral ischaemia in the rat. J Cereb Blood Flow Metab 16:932-940.

Mascarucci P, Perego C, Terrazzino S, De Simoni MG (1998) Glutamate release in the nucleus tractus solitarius induced by peripheral lipopolysaccharide and interleukin-1 $\beta$. Neuroscience 86:1285-1290.

Miller LG, Galpern WR, Dunlap K, Dinarello CA, Turner TJ (1991) Interleukin-1 augments $\gamma$-aminobutyric acid receptor function in brain. Mol Pharmacol 39:105-108.

Minami M, Kuraishi Y, Yamaguchi T, Nakai S, Hirai Y, Satoh M (1990) Convulsants induce interleukin- $1 \beta$ messenger RNA in rat brain. Biochem Biophys Res Commun 171:823-827.

Minami M, Kuraishi Y, Satoh M (1991) Effects of kainic acid on messenger RNA levels of IL- $1 \beta$, IL-6, TNF $\alpha$, and Lif in the rat brain. Biochem Biophys Res Commun 176:593-598.

Morganti-Kossmann MC, Kossmann T, Wahl SM (1992) Cytokines and neuropathology. Trends Pharmacol Sci 131:286-290.

Nishiyori A, Minami M, Takami S, Satoh M (1997) Type 2 interleukin-1 receptor mRNA is induced by kainic acid in the rat brain. Mol Brain Res 50:237-245.

Nitsch C, Goping G, Klatzo I (1986) Pathophysiological aspects of blood-brain barrier permeability in epilectic seizures. Adv Exp Med Biol 203:175-189.

Paxinos G, Watson C (1986) The rat stereotaxic atlas. New York: Academic.

Plata-Salamàn CR, ffrench-Mullen JMH (1992) Interleukin-1 $\beta$ depresses calcium currents in CA1 hippocampal neurons at pathophysiological concentrations. Brain Res Bull 29:221-223.

Rothwell NJ (1991) Functions and mechanism of interleukin-1 in the brain. Trends Pharmacol Sci 12:430-436.

Rothwell NJ, Hopkins SJ (1995) Cytokines and the nervous system II: actions and mechanisms of action. Trends Neurosci 18:130-136.

Scarborough DE, Lee SL, Dinarello CA, Reichlin S (1989) Interleukin$1 \beta$ stimulates somatostatin biosynthesis in primary cultures of fetal rat brain. Endocrinology 124:549-551.

Scharfman HE (1997) Hyperexcitability in combined entorhinal/hippocampal slices of adult rat after exposure to brain-derived neurotrophic factor. J Neurophysiol 78:1082-1095.

Schobitz B, De Kloet ER, Holsboer F (1994) Gene expression and function of interleukin 6 and tumor necrosis factor in the brain. Prog Neurobiol 44:397-342.

Schwarzer C, Sperk G, Samanin R, Rizzi M, Gariboldi M, Vezzani A (1996) Neuropeptides-immunoreactivity and their mRNA expression in kindling: functional implications for limbic epileptogenesis. Brain Res Rev 22:27-50.

Sheng JG, Boop FA, Mrak RE, Griffin WST (1994) Increased neuronal $\beta$-amyloid precursor protein expression in human temporal lobe epilepsy: association with interleukin- $1 \alpha$ immunoreactivity. J Neurochem 63:1872-1879.

Spranger M, Lindholm D, Bandtlow C, Heumann R, Gnahn H, Naher-
Noè M, Thoenen H (1990) Regulation of Nerve growth factor (NGF) synthesis in the rat central nervous system: comparison between the effects of interleukin-1 and various growth factors in astrocyte cultures and in vivo. Eur J Neurosci 2:69-76.

Streit WJ (1990) An improved staining method for rat microglial cells using the lectin from Griffonia simplicifolia (GSA I-B4). J Histochem Cytochem 38:1683-1686.

Takao T, Tracey DE, Mitchell WM, de Souza EB (1990) Interleukin-1 receptors in mouse brain: characterization and neuronal localization. Endocrinology 127:3070-3078.

Tancredi V, D'Arcangelo G, Grassi F, Tarroni P, Palmieri G, Santoni A, Eusebi F (1992) Tumor necrosis factor alters synaptic transmission in rat hippocampal slices. Neurosci Lett 146:176-178.

Taniwaki Y, Kato M, Araki T, Kobayashi T (1996) Microglial activation by epilectic activities through the propagation pathway of kainic acid induced hippocampal seizures in the rat. Neurosci Lett 217:29-32.

Traub RD, Miles R, Jefferys JG (1993) Synaptic and intrinsic conductances shape picrotoxin-induced synchronized after-discharges in the guinea-pig hippocampal slice. J Physiol (Lond) 461:525-547.

Turski WA, Cavalheiro EA, Calderazzo-Filho LS, Kleinrok Z, Czuczwar SJ, Turski L (1985) Injections of picrotoxin and bicuculline into the amygdaloid complex of the rat: an electroencephalographic, behavioral and morphological analysis. Neuroscience 14:37-53.

Vezzani A, Wu HQ, Tullii M, Samanin R (1986) Anticonvulsant drugs effective against human temporal lobe epilepsy prevent seizures but not neurotoxicity induced in rats by quinolinic acid: electroencephalographic, behavioral and histological assessments. J Pharmacol Exp Ther 239:256-262.

Vezzani A, Serafini R, Stasi MA, Vigano' G, Rizzi M, Samanin R (1991) A peptidase-resistant cyclic octapeptide analogue of somatostatin (SMS 201-995) modulates seizures induced by quinolinic and kainic acids differently in the rat hippocampus. Neuropharmacology 30:345-352.

Watkins JC (1978) Excitatory amino acids. In: Kainic acid as a tool in neurobiology (McGeer EG, Olney JW, McGeer PL, eds), pp 37-69. New York: Raven.

Westbrook GL, Lothman EW (1983) Cellular and synaptic basis of kainic acid-induced hippocampal epileptiform activity. Brain Res 273:97-109.

Yabuuchi K, Minami M, Katsumata S, Satoh M (1993) In situ hybridization study of interleukin-1 $\beta$ mRNA induced by kainic acid in the rat brain. Mol Brain Res 20:153-161.

Yamasaki Y, Matsuura N, Shozuhara H, Onodera H, Itojama Y, Kogure $\mathrm{K}$ (1995) Interleukin-1 as a pathogenetic mediator of ischemic bain damage in rats. Stroke 26:676-681.

Ye Z, Sontheimer H (1996) Cytokine modulation of glial glutamate uptake: a possible involvement of nitric oxide. NeuroReport 7:21812185.

Young AMG, Crowder JM, Bradford HF (1988) Potentiation by kainate of excitatory amino acid release in striatum: complementary in vivo and in vitro experiments. J Neurochem 50:337-345.

Zeise ML, Espinoza J, Morales P, Nalli A (1997) Interleukin-1 $\beta$ does not increase synaptic inhibition in hippocampal CA3 pyramidal and dentate gyrus granule cells of the rat in vitro. Brain Res 768:341-344. 